\title{
Borges leitor de Lovecraft
}

\section{Rosângela Fachel de Medeiros*}

\begin{abstract}
Resumo: Este artigo analisa o conto "There are more Abstract: The present article presents an analysis of things", de J. L. Borges, buscando desvelar a forma the short story "There are more things", by JL Borges, como o escritor argentino assume a identidade autoral and aims at revealing the way the Argentinian writer de H. P. Lovecraft, realizando o que ele intitula de um assumes the authorship of HP Lovecraft and produces conto póstumo do escritor estadunidense. Para tanto, what he calls a posthumous short story by the partimos dos pressupostos relacionados à autoria e à American writer. The article is based on theoretical leitura apregoados por Borges. assumptions related to authorship and reading as discussed by Borges.
\end{abstract}

Palavras- chave: Jorge Luis Borges; H. P. Lovecraft; Keywords: Jorge Luis Borges; H. P. Lovecraft; intertextualidade; autoria intertextuality; authorship

Imaginemos como propõe Ts'ui Pen ${ }^{1}$ que o tempo não é uniforme e nem absoluto, que existe em infinitas séries; divergentes, convergentes e paralelas, numa trama de tempos que se aproximam, se bifurcam, se cortam ou que se ignoram, abrangendo todas as possibilidades. Imaginemos que em um destes tempos Borges tenha lido a Lovecraft, em outro que Lovecraft tenha lido Borges, noutro ambos leram-se mutuamente e noutro nenhum contato houve entre eles.

Imaginemos então que Lovecraft tenha lido a Borges e que em um de seus contos exista a presença deste outro, do escritor argentino que o fascinou com seus labirintos, seus jogos de espelhos e suas bibliotecas infinitas; e que, assim como ele, entrara no universo de Scheherazade ainda criança e tinha em Edgar Allan Poe um mestre. Tal conto existe e podemos encontrá-lo em O Livro de Areia, de Borges, seu título: "There are more things".

Pensemos então como John Vincente Moon ${ }^{2}$ que talvez qualquer homem seja todos os outros e assim podemos concordar com o que escreveu Pierre Menard " ${ }^{3}$ Todo homem deve ser capaz de todas as idéias" (BORGES, 1989, p.38). E assim como Menard escreveu o

\footnotetext{
* Rosângela Fachel de Medeiros é graduada em Comunicação Social pela PUCRS, mestre e doutoranda em Literatura Comparada pela UFRGS.

${ }^{1}$ Ts'ui Pen é personagem do conto “O jardim dos caminhos que se bifurcam”, de J. L. Borges.

${ }^{2}$ John Vincente Moon é personagem do conto “A forma da espada”, de J. L. Borges.

${ }^{3}$ Pierre Menard é personagem do conto "Pierre Menard, autor do Quixote", de J. L. Borges.
} 
Quixote, Borges escreveu o conto de Lovecraft, pois é justamente escrevendo o conto que Borges realiza sua leitura do autor estadunidense. "There are more things" é um conto de Lovecraft lido por Borges, no qual a leitura se transformou em escritura.

\section{Lovecraft pelos olhos de Borges}

Para nossa incursão na análise comparatista entre o conto de Borges e a obra de H. P. Lovecraft faz-se necessária uma breve apresentação do escritor norte-americano. E nada melhor que utilizar a apresentação de Lovecraft escrita pelo próprio Borges em Introducción a la literatura norteamericana:

HOWARD PHILLIPS LOVECRAFT (1890-1937) nació en Providence, Rhode Island. Muy sensible y de salud delicada, fue educado por su madre viuda y sus tías. Gustaba, como Hawthorne, de la soledad y aunque trabajaba de día lo hacía con las persianas bajas. En 1924 se casó y fijó su residencia en Brooklyn; en 1926 se divorció y volvió a Providence, donde retomó su vida de soledad. Murió de cáncer. Detestaba el presente y profesaba el culto del siglo XVIII.Lo atraía la ciencia; su primer artículo trataba de astronomía. En vida publicó un solo libro; después de su muerte, sus amigos reunieron en volúmenes su obra considerable, antes dispersa en antologías y revistas. Estudiosamente imitó el patético estilo de Poe y escribió pesadillas cósmicas. En sus relatos hay seres de remotos planetas y de épocas antiguas o futuras que moran en cuerpos humanos para estudiar el universo o, inversamente, almas de nuestro tiempo que, durante el sueño, exploran mundos monstruosos, lejanos en el tiempo y en el espacio. Entre sus obras recordaremos The Colour Out of Space (El color que cayó del cielo), The Dunwich Horror (El horror de Dunwich), The Rats in the Wall (Las ratas en la pared). Dejó asimismo un epistolario copioso. Al influjo de Poe cabe agregar el del cuentista visionario Arthur Machen. (BORGES, 2000, p.54)

Nos parágrafos que lhe dedicou no capítulo "Novela policial, "Sience Fiction" y el lejano oeste", Borges demonstra conhecer não apenas a obra de Lovecraft, como suas leituras e também sua biografia, revelando assim sua leitura da Lovecraft. Exemplo disto é sua percepção da influência da obra de Poe sobre a de Lovecraft, que, segundo Borges, "estudiosamente imitó el patético estilo de Poe" (denunciando também sua própria relação com Poe). A presença da obra de Lovecraft entre as leituras de Borges se revela inquestionavelmente no epílogo de $O$ livro de areia quando o escritor argentino afirma a respeito do conto "There are more things":

O destino que, segundo a fama, é inescrutável, não me deixou em paz enquanto não perpetrei um contou póstumo de Lovecraft, escritor que sempre julguei um parodista involuntário de Poe. Acabei por ceder; o lamentável fruto se intitula "There Are More Things." (BORGES, s.d., p.323)

Em "Un secreto amante de la ciencia ficción”, Santis destaca que quando da publicação de $O$ Livro de Areia, chamou a atenção o fato de Borges resgatar a obra de um escritor cuja prosa sempre houvera depreciado. Porém, as acusações de Borges não devem ser 
levadas tão a sério, nem parecer-nos tão preocupantes, já que é notório seu prazer em criar provocações e polêmicas. Ademais, é no mínimo curioso que tal autor, imitador e/ou plagiador de Poe, acabe gerando uma reação tão forte sobre ele, a ponto de o destino obrigarlhe a perpetrar um conto póstumo de Lovecraft. A nós brasileiros, que tivemos em um defunto um de nossos mais famosos narradores, que nos agraciou com suas memórias póstumas, é interessante e instigante a idéia de um conto póstumo de Lovecraft, escrito por Borges.

A memória de Lovecraft evoca para Borges, além de Poe, a obra de Arthur Machen ${ }^{4}$ e a semelhança biográfica com Hawthorne, que pode ser estendida ao plano literário. Em $O$ Horror Sobrenatural na Literatura, Lovecraft nos apresenta suas leituras e realiza análises criticas a respeito destas obras. Neste livro, além de outros escritores, ele trata dos autores citados por Borges, dedicando a Poe um capítulo especial e a parte.

É interessante destacar que as primeiras traduções para o espanhol de textos de Lovrecraft foram realizadas na Argentina, na década de quarenta, com a publicação de dois livros que continha textos do autor pela editora Molino. Em 1957, a editora Minotauro publica a antologia chamada El color que cayó del cielo Porém o titulo em inglês, "There are more things", leva a crer que Borges tenha lido Lovecraft no idioma original e não em tradução, além de denunciar outra idiossincrasia do autor estadunidense, seu apresso pela cultura inglesa, "the literariy detective will have no trouble finding clues pointing to Lovecraft's lifelong Anglophilia; it surface even in his preference for English modes of spelling" (BLOCH, 1982, p.5), utilizando para tanto a memória de um trecho famoso do mais ilustre autor inglês, Shakespeare ${ }^{5}$. Deve-se enfatizar que também Borges, em sua formação como leitor foi em grande parte dominado pela literatura inglesa: "O certo é que me criei num jardim, atrás duma grade com lanças, e numa biblioteca de ilimitados livros ingleses" (MONEGAL, 1987, p.21).

Um fato ao qual Borges não alude, mas que, com certeza, o teria agradado muito, é a confusão autoral que se instituiu após a morte de Lovecraft. Uma vez que de sua imensa correspondência com outros escritores e leitores de ficções fantásticas nasceu o chamado Círculo de Lovecraft. Muitos dos membros deste círculo acabaram por escrever ao estilo do autor, utilizando elementos criados por ele e recorrentes em suas narrativas. O caso mais notório é o de August Derleth, detentor dos direitos de publicação da obra de Lovecraft, que publicou, além de contos conhecidos (publicados anteriormente em revistas), outros ainda

\footnotetext{
${ }^{4}$ Arthur Machen (1863-1947), escritor galês, que extraia o material para seus contos dos mistérios pagãos, da mitologia clássica e dos contos de fada.

5 “Há mais coisas no céu e na terra, Horácio, do que sonha a tua filosofia” - Hamlet, Ato I -CenaV.
} 
inéditos e também alguns que teriam ele e Lovecraft escrito em conjunto, nascendo assim uma desconfiança e confusão autoral muito borgeana.

Lembremos, por exemplo, de "Pierre Menard, autor do Quixote" e dos textos de Bustos Domecq ${ }^{6}$. No texto "Borges y la traducción", Sergio Pastormerlo ressalta que Borges "en algún momento de su juventud propuso a sus amigos, sin ningún éxito, la publicación de una revista literaria en la que las colaboraciones no llevaran firma” (PASTORMELO, 1999). Este jogo com a autoria, propagado pelo escritor, se desenvolveria "através de uma nova técnica da leitura, a técnica do anacronismo deliberado e das atribuições errôneas. Essa técnica de aplicação infinita [...] povoa de aventura os plácidos livros" (BORGES, 1989, p.38). E é esta a atitude que ele busca instigar em seu leitor, que não apenas aceite o texto, mas que ao lê-lo, o reescreva. E é este o perfil do Borges leitor, conforme define Emir Rodríguez Monegal, "a primeira máscara de Borges é a de leitor e tradutor" (MONEGAL, 1982, p.24).

Como se percebe, Borges possui um bom conhecimento, ou melhor, uma boa leitura da obra de Lovecraft. E, como para ele, leitor e autor se confundem, sendo uma única entidade, não é difícil compreendermos "There are more things" como um conto póstumo de Lovecraft.

\section{2 À memória de Howard P. Lovrecraft}

À primeira leitura do conto "There are more things" podemos sentir um certo estranhamento e ansiedade ao não reconhecermos imediatamente o estilo de Borges. Mas se já houvermos, mesmo que rapidamente, adentrado a ficção de Lovecraft e suspeitarmos da dedicatória de Borges logo reconheceremos a escritura do estadunidense e apreciaremos seu conto póstumo.

A dedicatória "à memória de Howard P. Lovecraft" não deve passar ingenuamente, primeiro por Borges dirigir-se a Howard P. Lovecraft, quando o escritor é sempre referido como H. P. Lovecraft, uma pista da relação diferencial que ele parece desejar instituir com o autor, uma intimidade que o permite chamá-lo pelo primeiro nome. Tendo em mente também que para Borges a memória tem um significado especial. Pensemos, por exemplo, no que diz Menard: "Minha lembrança geral do Quixote, simplificada pelo esquecimento e a indiferença, pode muito bem equivaler à imprecisa imagem anterior de um livro não feito" (BORGES,

\footnotetext{
${ }^{6}$ Bustos Domecq foi o codinome utilizado por Borges e Bioy Casares para assinar os textos que escreveram em conjunto.
} 
1989, p.35). Para Borges, é através do jogo entre memória e esquecimento que se define a leitura e nela a escritura. E é este jogo que origina "There are more things", imagem de um conto não feito por Lovecraft e por isto mesmo seu.

Ao analisar o conto de Borges perceberemos sua leitura da obra do estadunidense já que ele articula vários dos topos recorrentes na obra de Lovecraft.

No conto, o narrador em primeira pessoa narra em flash-back os estranhos acontecimentos ocorridos após a venda da Casa Colorada, que pertencera a um tio que morrera. Os comentários a respeito de acontecimentos estranhos envolvendo a casa e o mistério em torno do comprador instigaram a curiosidade do narrador, incitando-o à investigação. Procurando conversar com pessoas que tiveram algum contato com a casa ou com seu misterioso comprador. Depois passando a rondar a casa à noite para observá-la. $\mathrm{O}$ que fez o mistério se intensificar e o narrador se empenhar cada vez mais em desvendá-lo, culminando com sua entrada na casa, onde se depara com uma mobília estranha que parece não ter relação com a fisiologia humana. Ao final do conto, o narrador defronta-se com um Ser indescritível, porém ele não descreve o que apenas a curiosidade não o impedira de olhar. A distância temporal entre o narrado e o momento em que é feia narração não é informada. Sabe-se que o narrador conseguiu sobreviver ao encontro com esse Ser de outro planeta e/ou tempo já que ele está contando o ocorrido em flash-back, mas o que houve neste encontro jamais saberemos.

No primeiro parágrafo do conto, já aparece uma idiossincrasia de Lovecraft, a utilização de um jovem universitário como protagonista. Como salienta Robert Bloch, em Heritage of Horror": "His narrators are usually scientists or scholars of a high intellectual order who address the reader with obvious authority" (BLOCH, 1982, p.13). O interesse do autor por tais personagens é evidenciado por sua criação da ficcional Miskatonic University, local de origem de muitos de seus personagens e narradores, e presente em vários de seus contos. No conto de Borges, o narrador nos informa que na época em que tudo acontecera, era um jovem universitário prestes a se graduar em filosofia pela Universidade do Texas.

Quando o narrador regressa à Argentina, a antiga Casa Colorada, que pertencera ao tio Edwin Arnett, já fora vendida. As melhores recordações que mantinha do tempo em que convivera com o tio estavam ligadas à casa que fora construída pelo arquiteto Alexander Muir, amigo íntimo de seu tio. Borges re-articula assim outro topos recorrente na obra de Lovecraft, a casa antiga, casa dos ancestrais, casa mal assombrada: "Old houses and old

\footnotetext{
${ }^{7}$ Robert Bloch era amigo e protegido de Lovecraft; é autor de "Psycho" - 1959 (adaptado para o cinema por Hitchock, em 1960).
} 
tombs are abundantly in evidence and often their presence is unpleasant, even unnatural. Ancient edifices hold monstrous secrets in 'The Rats in the Walls', 'The Lurking Fear', 'The Shadow Over Innsmouth', 'The Shadow Out of Time', 'The Shunned House', 'The Dreams in the House' and a dozen other tales" (BLOCH, 1982, p.5).

A imagem da casa mal assombrada, lugar de acontecimentos inexplicáveis que faz da casa quase um ser vivo, é uma constante das narrativas de terror ${ }^{8}$. Basta lembrar o emblemático conto de Poe, "A Queda da Casa de Usher" e o romance A Casa das Sete Torres, de Nathaniel Hawthorne, que certamente estão na memória do conto de Borges e da obra de Lovecraft. As impressões que tais obras deixaram em Lovecraft podem ser conhecidas através de seu livro O Horror Sobrenatural na Literatura. Diz Lovecraft que especialmente em "A Queda da Casa dos Usher", Poe assume o seu lugar à testa dos "miniaturistas ficcionais [...] a superioridade em detalhes e proporções é marcante" (LOVECRAFT, 1987, p.53). Ele resume o conto: "uma longa e retirada história de família um irmão, sua irmã gêmea e a casa incrivelmente antiga, todos partilhando uma única alma e encontrando uma dissolução comum na mesma hora" (LOVECRAFT, 1987, p.53).

Assim também, ao comentar o romance de Hawthorne ,fica evidente a predileção de Lovecraft por essa obra específica do autor: "Mas, como peça artística acabada, dentre todo o material fantástico do nosso autor destaca-se o famoso e primorosamente elaborado romance A Casa das Sete Torres" (LOVECRAFT, 1987, p.60).

Além disso, Lovecraft realiza uma aproximação entre as duas obras: "A malevolência opressiva do velho casarão [referindo-se ao romance de Hawthorne] quase tão vivo quanto a casa de Usher de Poe" (LOVECRAFT, 1987, p.60). Fica evidente sua estima por essas duas obras e seus autores. Mas o que ele mais prestigia nas obras que analisa é o terror que essas podem proporcionar em seus leitores. Dessa forma, ao analisar a obra de Poe, deixa de lado seus contos policiais.

Borges também salienta a importância da contística de Poe: "Poe se creía poeta, sólo poeta, pero las circunstancias lo llevaron a escribir cuentos, y esos cuentos a cuya escritura se resignó y que debió encarar como tareas ocasionales son su inmortalidad" (POE, 1996, p.1). Porém é notória sua predileção pelos contos de raciocínio, dos quais, segundo Borges, nasce o gênero policial:

\footnotetext{
${ }^{8}$ Leyla Perrone-Moisés no texto "A fantástica verdade de Clarice", trata do topos da casa assombrada no conto "A Mensagem", partindo de dois exemplos: "A estranha casa entre as brumas" de Lovecraft e "A Queda da Casa de Usher" de Poe.
} 
De otros (Los crímenes en la Rue Morgue, La carta robada) procede el caudaloso género policial que hoy fatiga las prensas y que no morirá del todo, porque también lo ilustran Wilkie Collins, Stevenson y Chesterton. Detrás de todos, animándolos, dándoles fantástica vida, están la angustia y el terror de Edgar Allan Poe. (BORGES, 1996, p.1)

Percebemos assim, como a leitura de Borges da obra de Poe vai por um viés diferente da de Lovecraft. A Borges interessa, como bem destaca Santiago Rodrígez em "Idea de Edgar A. Poe en la obra crítica de Jorge Luis Borges":

en especial los cuentos y el ensayo "The Philosophy of Composition". De los cuentos, en especial de los policiales, toma elementos claves para su literatura: Así, el uso simbólico de la biblioteca o el narrador en los cuentos policíacos. (GUERREIRO-STRACHAN, 1999)

Já Lovecraft centra sua atenção sobre os contos em que, segundo ele, se inaugura a moderna história de horror. Ambos porém, não saem ilesos à leitura da obra de Poe e estas leituras, realizadas por ambos, se mesclam em "There are more things".

Em um paralelo entre o texto de Poe e o de Borges se reconhece na Casa Colorada a reconfiguração da Casa de Usher. Vejamos como Poe descreve a casa de Usher:

A casa simples, os aspectos simples da paisagem da propriedade, as paredes glaciais, as janelas vazias, semelhando olhos, uns poucos canteiros de caniços e uns poucos troncos brancos de árvores mortas [...] a margem escarpada de um pantanal negro e lúgubre, que reluzia, parado junto ao prédio. [...] Sua feição dominante parecia ser duma excessiva antigüidade. Fora grande o desbotamento produzido pelos séculos. (POE, 1985, p.66-8)

Vejamos agora como Borges descreve a Casa Colorada:

A Casa Colorada estava em um alto, cercada, em direção ao poente, por terrenos alagadiços. Do outro lado da cerca, as araucárias não mitigavam seu ar pesado. Em lugar de sotéias, havia telhados de ardósias de duas águas e uma torre quadrada com um relógio, que pareciam oprimir as paredes e as parcas janelas. (BORGES, s.d., p.53-4)

A memória da casa de Usher habita a Casa Colorada. Primeiro pela negação, pois a casa de Borges é colorada e não desbotada como a casa de Poe, mas este desbotamento aparecerá em outros textos de Borges. A aproximação se dá também através da semelhança, uma vez que a imagem do terreno alagadiço do pântano próximo à casa aparece nas duas descrições. Assim, a degradação da natureza está presente nas paisagens descritas em ambas as narrativas, surgindo como um reflexo de algo horrível que está acontecendo, ou que está para acontecer. Uma manifestação presente também nos textos de Lovecraft: "Estos cimientos eram muy curiosos, y por uno de los lados se confudían insensiblemente com la piedra caliza del precipicio des.d.e cuyo borde el antiguo priorato se asomaba a un valle desolado" (in: LLOPIS, 1982, p.282). Assim como a transformação da casa em um lugar assustador e cheio de mistério que ocorre no conto de Borges: "Era quase noite. Ao divisar a umas quadras a 
Casa Colorada no alto, Iberra se desviou" (BORGES, s.d., p.255); é uma imagem recorrente na obra de Lovecraft:

Referiam-se à casa que ficava no local que viria a ser a charneca maldita... a linda casa branca de Nahun Gardner, no meio de férteis jardins e pomares [...] Tudo que era vivo havia desaparecido. Sobrava uma gleba medonha de deserto cinza e poeirento, e nunca mais coisa alguma medrou ali. (LOVECRAFT, A cor que caiu do céu, 1998, p.10-32)

A Casa Colorada é memória e esquecimento das inúmeras casas que povoam a escritura de Lovecraft. Casa dos ancestrais enraizada à própria família como a amaldiçoada Casa das Sete Torres, dos Pyncheon; ou a Casa de Usher, cujo nome já evidencia a hibridização da casa com a família, que sucumbirá juntamente com o fim da linhagem dos Usher. Em “Las Ratas de las paredes”, de Lovecraft, a casa também está ligada a uma família maldita, os De la Poer, guardando em suas paredes um segredo terrível. O último descendente dos De la Poer começa a reforma da casa 1921 coincidentemente o mesmo ano em que o narrado de Borges regressa à pátria, ou seja, os dois mistérios iniciam-se no mesmo ano.

É interessante contrastarmos também a reação dos narradores quanto à visão da casa. Primeiro em “A Queda da Casa de Usher”, de Poe:

Não sei como foi, mas, ao primeiro olhar sobre o edifício, invadiu-me a alma um sentimento de
angustia insuportável; digo insuportável, porque o sentimento não era aliviado por qualquer
dessas semi-agradáveis, porque poéticas, sensações com que a mente recebe comumente até
mesmo as mais cruéis imagens naturais de desolação e de terror. [...] Fui forçado a recair na
conclusão insatisfatória que se há, sem dúvida, combinações de objetos muito naturais, que têm
o poder de assim influenciar-nos, a análise desse poder, contudo permanece, entre as
considerações além de nossa argúcia. (POE, 1985, p.66)

Já o narrador de Borges apresenta uma recordação infantil, sendo a infância seu elo com a casa: "Em pequeno, eu aceitava essas fealdades como se aceitam essas coisas impossíveis que só pela razão de coexistirem levam o nome de universo" (BORGES, s.d., p.254).

Também o narrador de Hawthorne carrega recordações infantis da Casa das Sete Torres, as quais emergiram quando de seu encontro com a casa arruinada: "Desde minha meninice, ela foi objeto de curiosidade como espécie de uma sólida arquitetura de época remota e cenário de acontecimentos mais cheios de interesse humano que um cinzento castelo feudal" (HAWTHORNE, s.d., p.11).

Assim, o Lovecraft de Borges não é um mero imitador e/ou plagiador de Poe, mas instaura um diálogo intertextual com seu texto. Escrevendo com a memória de Lovecraft, Borges joga com a relação existente entre ele e Poe, mediados pela interferência de sua presença e de sua leitura. Enquanto em Poe existem combinações de objetos naturais capazes 
de influenciar o narrador, gerando a sensação inexplicável que lhe angustia; para o narrador borgeano todas as coisas que formam o universo são impossíveis. Ou seja, a casa para o narrador de Poe, apesar de comum e simples cria sensações angustiantes; enquanto o narrador borgeano reconhece a estranheza da casa, sua fealdade, mas a aceita sem inquietação, pois, para ele, o impossível compõe o universo.

Após a compra da Casa Colorada pelo forasteiro, Max Preetorius, inicia-se o mistério em relação à casa, surgem comentários sobre acontecimentos estranhos, os quais instigam a curiosidade do narrador, que decide investigar o assunto. A maior parte da investigação se dá através de conversas, mas seu último passo para desvendar o mistério é entrar na casa.

A ruptura com a normalidade se dá a partir da chegada de Preetorius que instala o mistério na comunidade. Ou seja, o estranho vem do exterior, vem de fora. Em Lovecraft este estranho é personificado em seres de planetas remotos e/ou de outras épocas, passadas ou futuras. Quando do desaparecimento de Preetorius, o que se comenta é que tenha deixado o país.

A "movimentação noturna" na Casa Colorada: as reformas na casa são feitas sempre à noite e é também durante a noite que se instala na casa o novo habitante; repete uma constante na obra de Lovecraft, onde as ações que se pretendem secretas, acabam sempre sendo observadas por alguém e se transformam em inquietação e mistério: "as idas e vindas noturnas dos caminhões contribuíam para as lúgubres especulações” (LOVECRAFT, 1988, p.96). E quando Preetorius deseja reformar a casa não consegue que os carpinteiros locais aceitem o trabalho, precisando contratar pessoas de outra cidade; da mesma maneira, no conto de Lovecraft: "Contraté algunos obreros para comezar su reconstrucción material. Para contratar-los, me vi obligado a ir al pueblo próximo, pues los aldeanos de Anchester tenían una aversion y un pánico tan casi increíbles al lugar [...] que incluso llegó a contagiar en ocasiones a los trabajadores del outro pueblo, causando entre ellos muchas deserciones". (LOVECRAFT, 1982, p.285) No conto de Lovecraft é a própria casa que gera o temor junto aos trabalhadores, como se sua existência fosse a perpetuação de um terror confuso (lembrado e esquecido) e ela possuísse em sua edificação a essência deste mal, instituído ali no passado. Em Borges a Casa Colorada sofre uma transformação linear: o misterioso Preetorius realiza esquisitas reformas que afugentam os trabalhadores locais e, após essa reforma, a casa transforma-se em local proibido e perigoso que exerce repulsa junto aos moradores locais.

Também recorrente na literatura de Lovecraft é o fechamento da casa como se um universo à parte e aterrador fosse instituído dentro dela, sendo as portas e janelas fechadas para não mais serem abertas. No conto de Borges, durante as reformas noturnas, as portas 
permanecem fechadas e, após as reformas, as janelas não são mais abertas. Lovecraft utiliza como indício de atividades suspeitas realizadas no interior da casa a presença de luzes que irrompem da casa durante a noite: "as horas nas quais as luzes eram vistas, [...] e a quantidade de vozes ouvidas freqüentemente em conversas abafadas em horas totalmente inadequadas [...] e com estranhos brilhos em suas janelas a todas as horas da noite" (LOVECRAFT, 1988, p.16). Esse elemento é também recuperado por Borges; “As janelas já não se abriam, porém na escuridão se divisavam frestas de luz" (BORGES, s.d., p.254).

A descoberta do ovelheiro morto, mutilado e decapitado é mais uma pista de que algo estranho está acontecendo na Casa Colorada. A mutilação é outra imagem muito utilizada por Lovecraft, principalmente a mutilação de cadáveres que representa a ruptura do equilíbrio cósmico e faz surgir o hediondo. Em "Las ratas de las Paredes", o retorno do filho inválido e mutilado após suas investigações a respeito da antiga casa da família prenuncia a desgraça associada à casa.

Outro elemento recorrente nas narrativas de Lovecraft é o poço que aparece como um lugar misterioso que configura o medo do desconhecido. Esse poço é geralmente a moradia de seres extraordinários: seres cósmicos, monstros atemporais, ou horríveis seres disformes e mutantes. Em "A Cor que Caiu do Céu”, no poço habita o ser cósmico responsável pela degradação da região:

\begin{abstract}
Não podia evitar olhar nervosamente para a cimalha de pedra ao redor do poço, e quando um detetive lhe perguntou por que agia assim, ele admitiu que Nahum expressara temor de alguma coisa que existia lá embaixo [...] Depois disto os homens decidiram que deveriam esvaziar e explorar o poço. [...] Não há por que se falar do que encontraram. Tanto Mervin como Zenas estavam ali, em parte, muito embora os vestígios fossem ossos. Havia também dentro do poço um veadinho e um cão, mais ou menos no mesmo estado. (LOVECRAFT, 1998, p.25)
\end{abstract}

No conto de Borges também aparece um fosso: “À esquerda havia um fosso de escassa profundidade e os bordos estavam pisoteados" (BORGES, s.d., p.256). O pisoteado em torno do fosso sinaliza a grande movimentação nesta área provavelmente para abandonar ali dejetos, que, devido à memória dos textos de Lovecraft e ao ovelheiro mutilado, logo imaginamos terríveis.

A presença de cheiros pestilentos, nas obras de Lovecraft, está geralmente ligada à decomposição, à presença de material orgânico em putrefação seja devido aos sacrifícios ou às experiências científicas. Igualmente: "Um cheiro doce e nauseabundo" penetra a Casa Colorada (BORGES, s.d., p.257). O cheiro nauseabundo dá pista de algo em apodrecimento, mas ao diálogo com as narrativas de Lovecraft, esse pequeno detalhe recebe perspectivas mais evidentes. Associando a presença desse odor nauseante à lembrança do ovelheiro mutilado e 
do fosso, apresentados anteriormente, as imagens de Lovecraft começam a despertar, através das pistas lançadas por Borges.

Um dos mecanismos mais comuns no conto de mistério e policial é a investigação através das informações conseguidas junto a outras pessoas, que vão sendo encaixadas como peças de um quebra-cabeça. Ao contrário do que Borges realiza em outros contos nos quais subverte a estrutura do conto policial analítico clássico, criado por Poe, em "There are more things", as pistas lançadas durante a narrativa corroboram a elucidação do mistério. Assim, a memória dos contos policiais é um dos alicerces que estruturam a narrativa. O narrador busca, através das conversas, informações para elucidar o mistério, procedimento freqüentemente realizado pelos personagens de Lovecraft, que levam suas investigações sempre até às últimas conseqüências.

Um dos topos mais marcantes da escritura de Lovecraft são os seres extraordinários que irrompem na realidade das personagens, como percebe Borges: "En sus relatos hay seres de remotos planetas y de épocas antiguas o futuras que moran en cuerpos humanos para estudiar el universo" (BORGES, 2000, p.54). Para ilustrar esta característica, tomemos como exemplo um trecho do conto de Lovecraft, citado por Borges, "A cor que caiu do céu”:

Do que se trata, Só Deus sabe. (...) Aquilo não era criatura dos mundos e sóis que rebrilham aos telescópios e nas chapas fotográficas de nossos observatórios. Era tão somente uma cor caída do céu... um mensageiro assustador vindo de reinos informes da infinitude, além de tudo quanto conhecemos como natural; de reinos cuja mera existência atordoa o cérebro e nos entorpece com os negros abismos supracósmicos que desvela diante de nossos olhos aturdidos. (LOVECRAFT, 1998, p.33)

Na sua leitura/escritura da obra de Lovecraft, Borges rearticula seu discurso crítico dentro da narrativa ficcional, recriando um desses seres cósmicos de Lovecraft:

Como seria o habitante? Que podia buscar neste planeta, não menos atroz para ele que para nós? De que secretas regiões da astronomia ou do tempo, de que antigo e agora incalculável crepúsculo, haveria alcançado este arrabalde sul-americano e esta precisa noite? (BORGES, s.d., p.258)

Borges capta a essência dos seres de Lovecraft, a angústia gerada por algo que não se enquadra dentro de nossos padrões, estando fora de nosso entendimento: "Não tratarei de descrevê-los porque não estou seguro de tê-los visto, apesar da desapiedada luz branca. Explicarei. Para ver uma coisa é preciso compreendê-la" (BORGES, s.d., p.257). O narrador explica “A poltrona pressupõe o corpo humano", e: "Nenhuma das formas insensatas que essa noite me deparou correspondia à figura humana ou a um uso concebível" (BORGES, s.d., p.257). A estranha estrutura da casa e seus móveis revelam um ser não humano, estranho, que se movimenta "opressivo, lento e plural” (BORGES, s.d., p.258). 
Enquanto Lovecraft descreve seus monstros horríveis, tentando a visualização de suas formas ilógicas e impossíveis:

Os integrantes da Grande Raça eram imensos cones rugosos de três metros de altura, com a cabeça e outros órgãos presos a membros telescópicos de palmo e meio de largura, que saiam dos ápices. Falavam estalando ou arranhando as imensas patas ou garras na extremidade de dois de seus quatro membros, e caminhavam mediante a expansão e contração de uma camada viscosa ligada às suas amplas bases, de três metros. (LOVECRAFT, 1998, p.145)

O narrador de Borges não se empenha em descrever, por não compreender, e não compreendendo é como se não visse. Ele insinua mais do que revela e o máximo que nos apresenta é seu pensamento de que há na casa um habitante de "monstruosa anatomia" (BORGES, s.d., p.258). O narrador dá alguns sinais, mas deixa que o leitor imagine como é este ser misterioso. A proposta é imaginarmos o habitante a partir do pouco da casa e dos móveis que o narrador descreve, imaginando para que serviriam. Como a poltrona pressupõe o corpo humano através de suas partes e articulações, tais móveis devem pressupor o estranho ser:

Lembro agora de uma espécie de grande mesa operatória, muito alta, em forma de U, com cavidades circulares nos extremos. Pensei que podia ser o leito do habitante, cuja monstruosa anatomia se revela assim, obliquamente, como um animal ou um deus, por sua sombra. [...] Assim mesmo recordo um $\mathrm{V}$ de espelhos que se perdia na treva superior. (BORGES, s.d., p.258)

Este Ser com a extremidade superior bifurcada, que se mirar no V de espelhos, poderia muito bem figurar no bestiário redigido por Borges, O livro dos seres imaginários, já que a anfisbena, imagem que o narrador usa para sugerir o misterioso habitante, mas que não esgotaria com certeza o que seu olhos iriam ver, faz parte deste manual:

A Anfisbena é a serpente com duas cabeças, uma em seu lugar e outra na cauda; e com as duas pode morder, e corre com ligeireza, e seus olhos brilham como candeias'. No século XVII, Sir Thomas Browne observou que não existe animal sem embaixo, em cima, na frente, atrás, esquerda e direita, e negou que pudesse existir a anfisbena, em que ambas as extremidades são anteriores. Anfisbena, em grego, quer dizer que vai em duas direções. Nas Antilhas e em certas regiões da América, o nome se aplica a um réptil habitualmente conhecido por doble andadora, por serpente de duas cabeças e por mãe-das-formigas. Diz-se que as formigas a sustentam. Também que, se a cortam em dois pedaços, estes se juntam. As virtudes medicinais da anfisbena já foram celebradas por Plínio. (BORGES, 1981, p.5)

Em $O$ Livro dos Seres Imaginários, Borges embrenha-se no universo de seres imaginários, mitológicos e literários; "estranhos entes que engendrou, ao longo do tempo e do espaço, a fantasia dos homens" (BORGES, 1981, p.XI). Resgatando os seres extraordinários imaginados por Poe e Kafka e também os que povoam a Eneida, a Odisséia e As Mil e Uma Noites. 
Estes seres imaginários circulam pela obra de Borges, tendo sua manifestação mais notória e significante, centrada na figura do Minotauro, que tantas vezes se manifesta em sua obra. Mas é no conto à memória de Lovecraft que emergem mais livremente. Através da idiossincrasia da obra do escritor estadunidense, Borges realiza o diálogo com os seres extraordinários que habitaram suas leituras infantis e perpetuaram-se em sua memória literária.

\section{Borges: o outro em seu próprio texto}

Borges insere-se dentro do texto como se através desta intromissão no conto póstumo de Lovecraft contasse ao leitor que ele também entrara no universo do escritor estadunidense e reconhecera no seu universo literário muito do que também lhe inquietava, havendo entre suas obras uma inesperada convergência. Por exemplo, em relação à percepção do tempo que é compartida por ambos:

Minha concepção do tempo - a capacidade de distinguir entre consecutividade e simultaneidade - parecia sutilmente desordenada, de forma que eu alimentava idéias quiméricas a respeito de se viver numa época e lançar o espírito por sobre toda a eternidade, obtendo conhecimento de idades passadas e futuras. (LOVECRAFT, 1998, p.152)

Não é difícil reconhecer a semelhança entre a assimilação temporal presente nesse personagem de Lovecraft e a idéia de tempo não linear trabalhada por Borges em seus $\operatorname{contos}^{9}$. Outra confluência é a respeito da imagem da Biblioteca que povoa suas obras:

Suas imensas bibliotecas encerravam compêndios de textos que continham a totalidade dos anais da Terra - histórias e descrições de todas as espécies que já haviam existido ou que viriam a existir, com exposições minudentes de suas artes, suas realizações, suas línguas e suas psicologias. (LOVECRAFT, 1998, p.161)

A leitura deste trecho faz recordar a imagem da biblioteca total de Borges. Imagem na qual novamente os dois escritores dialogam com a obra de Poe.

Lovecraft, assim como Borges, inventou escritores e livros, e misturava-os a escritores e obras reais. Sua mais famosa invenção, o livro Necronomicon escrito pelo árabe louco Abdul al-Hazred é citado inúmeras vezes em seus $\operatorname{contos}^{10}$ e transformou-se em ícone da literatura de terror, a ponto de muitos leitores duvidarem que ele seja uma criação do escritor,

\footnotetext{
${ }^{9}$ A questão do tempo é magistralmente exemplificada em contos como: "Jardim dos Caminhos que se Bifurcam”, "O Milagre Secreto", "A Outra Morte".

${ }^{10}$ Personagem que também parecerá em narrativas de outros escritores, muitos dos quais pertencentes ao Círculo de Lovecraft, que cultivaram o estilo do autor norte-americano.
} 
acreditando em sua real existência. A confusão gerada a respeito da existência ou não do livro não deve ter sido a intenção de Lovecraft, mas com certeza seria a de Borges.

A tradição que Lovecraft criou para o blasfemo livro envolve uma questão muito relevante para Borges, a tradução. Segundo consta nas narrativas, a versão árabe original do Necronomicon fora perdida, mas o texto havia sido traduzido para o grego e do grego para o latim, sendo conhecido então neste idioma. O livro tornou-se um objeto procurado por muitos. Esta trajetória realizada pelo texto através de suas traduções bem poderia ter sido criada por Borges.

Talvez a mais importante aproximação entre eles seja enquanto leitores, possuindo muitas leituras em comum. Ambos percorreram as mesmas obras e se apaixonaram pelo universo de Scheherazade. O árabe autor do Necronomicon nasceu das leituras de Lovecraft de As Mil e Uma Noites e as incursões desta obra nos textos de Borges são quase incontáveis. O interessante é que mesmo compartilhando uma mesma memória literária, diferentes caminhos são traçados, criando a identidade literária de cada um dos escritores e gerando obras muito díspares, mas que não deixam de se tangenciar. Borges com seu conto "There are more things" expõe isso.

Dentro do conto, Borges aparece como Outro, um reflexo de sua própria obra na obra alheia, magistralmente ludibriador, sua presença se manifesta como um dos diversos textos presentes à tessitura da narrativa.

No conto "Las Ratas de las Paredes", de Lovecraft, o narrador retorna à terra de seus antepassados, a Inglaterra, para recuperar e reformar a casa que fora de sua família, iniciandose o extraordinário. Em "There are more things", a pátria de retorno do narrador é a Argentina, Borges parece desejar infiltrar-se, como memória, no imaginário de Lovecraft, deslocando seus mistérios para os "confins remotos do continente" (BORGES, s.d., p.253).

Como leitor, que joga com o autor e com o texto, Borges entra na obra de Lovecraft, recuperando e rearticulando topoi recorrentes na obra do estadunidense, aclimatando-a e marcando no texto a sua presença.

Monegal, em seu livro Borges por Borges, revela alguns dos germes das inquietações metafísicas de Borges, que têm suas raízes:

naquelas conversas de menino com o Pai, quando este usando um tabuleiro de xadrez, lhe ensinava os paradoxos de Zenão de Eléia, ou inquietava seus sonhos perguntando-lhe (sem mencionar Berkeley) se o sabor ou a cor da laranja estavam na laranja ou nas pessoas que as percebiam. (MONEGAL, 1987, p.47) 
Esta inquietação metafísica está presente em "There are more things" onde o escritor rearticula suas próprias memórias pessoais na trama ficcional:

A matéria que eu cursava era filosofia; recordei que meu tio, sem invocar um só nome próprio, me havia revelado suas belas perplexidades. (...) Uma das laranjas de sobremesa foi seu instrumento para iniciar-me no idealismo de Berkeley; ou o tabuleiro de xadrez lhe bastou para os paradoxos eleáticos. (BORGES, s.d., p.253)

Mas mesmo sendo as questões metafísicas tão presentes na obra de Borges e marcando tanto sua passagem pelo texto, tal incursão passaria desapercebida no universo de Lovecraft, podendo ser incorporada por seu texto, já que tal inquietação se faz também presente em sua obra.

Contudo, as pegadas deixadas por Borges são muitas, como, por exemplo, no sonho do narrador:

Sonhei com uma gravura à maneira de Piranesi, que nunca havia visto ou que havia visto e esquecido e que representava o labirinto. Era um edifício de pedra, cercado de ciprestes e mais alto que a copa dos ciprestes. Não havia portas nem janelas, mas sim uma fileira infinita de frestinhas verticais e estreitas. Com um vidro de aumento, eu procurava ver o minotauro. Ao fim, percebi-o. Era o monstros dos monstros; tinha menos de touro que de bisonte e, estendido na terra o corpo humano, parecia dormir e sonhar. Sonhar com quê ou quem? (BORGES, s.d., p. 256)

O labirinto e o minotauro são constantes do imaginário borgeano. Porém, o mais interessante nesta passagem é que a procura dentro da gravura de Piranesi com uma lente de aumento foi realmente realizada pelo menino Borges, que buscava, como o narrador em seu sonho, encontrar ali o minotauro. Ao comentar a exposição, "Universo de Borges”, Beatriz Sarlo diz; "Hay un grabado de Piranesi (...) Piranesi muestra su arquitectura sombría, de falsas simetrías y falsos empalmes: perspectivas imaginarias" (SARLO, 2000). A presença da obra de Piranesi na exposição, que homenageava o autor, constata a relevância dessa no universo de Borges.

Poderíamos perguntar-nos então: com quê ou quem sonha o minotauro? Se lembrarmos de outro conto de Borges, "A casa de Asterion", imaginaremos que provavelmente ele sonhava com seu redentor, com Teseu, que viria para libertá-lo, assim como ele liberta os nove jovens, que, a cada nove anos, entram em sua casa. Em sua espera, Asterion questiona-se a respeito da forma de seu redentor: "Como será meu redentor? - me pergunto. Será um touro ou um homem? Será talvez um touro com cara de homem? Ou será como eu?" (BORGES, 1972, p.53). O narrador, em “There are more things", também se questiona sobre a morfologia do habitante da Casa Colorada: "Como seria o habitante?" (BORGES, s.d., p.258). 
Ambos terão resposta, Asterion finalmente encontrará seu redentor, Teseu, um homem, não um ser híbrido como ele. O narrador de "There are more things" também conseguirá visualizar o habitante, que ele imagina possuir uma monstruosa anatomia; “A curiosidade pôde mais que o medo e não fechei os olhos" (BORGES, s.d., p.258). Ele confronta o habitante, não temendo o que iria ver, afinal para isto entrara na casa. Este confronto do homem com um ser extraordinário povoa o imaginário humano; o encontramos na mitologia: Édipo e a Esfinge, Perseu e a Medusa; e configura a abundante cinematografia de ficção científica, nos chamados contatos com alienígenas. Este contato com seres de outros planetas, sempre assustador, é recorrente na obra de Lovecraft e é perfeitamente articulado por Borges já que há uma memória comum aos dois autores.

A Casa Colorada, assim como o Labirinto, não cria obstáculo a quem desejar entrar: "Não sei se com temor ou com esperança experimentei o portão. Inesperadamente, cedeu. [...] Também a porta da casa estava entreaberta" (BORGES, s.d., p.257). E o narrador, assim como Teseu, não tem dificuldade em adentrar o local de mistério e temor, morada do ser desconhecido. Há, porém, uma tensão dicotômica: encontrar ou ser encontrado.

Em sua aclimatação do texto de Lovecraft, Borges incorpora à narrativa um personagem seu: Daniel Iberra, gaúcho valente, irmão menor de Juan Iberra, com que protagonizou "Milonga de los dos hermanos" (1965). Desta vez, contudo, o corajoso Iberra teme algo e deseja desviar-se da Casa Colorada. Ao ser questionado pelo narrador sobre o motivo desta atitude, ele responde:

- Sou o braço direito de Don Felipe. Ninguém me chamou de covarde. Lembrar-te-ás daquele
moço de Urgoiti que se atirou a me provocar em Merlo e do que houve com ele. Há algumas
noites, eu vinha de uma farra. A pouco mais de cem metros da quinta, vi algo. O tubiano se
espantou e, se não me seguro, talvez não contasse a história. O que vi não era para menos.
(BORGES, s.d., p.255)

A leitura deste trecho evoca a imagem dos duelos recorrentes na obra de Borges ${ }^{11}$, bem como da tradição oral viva entre os gaúchos, pois, a maneira como Iberra conta-lhe o que aconteceu remete aos conhecidos "causos", contados em roda de fogueira. O escritor articula em seu conto o gaúcho, acostumado ao duelo e à vida no pampa, e o Ser de outro planeta. Talvez esta seja sua marca mais forte no conto, uma vez que tal articulação seria impossível em uma narrativa de Lovecraft, completamente estranho à figura do gaúcho. Borges abre uma lacuna na escritura de Lovecraft e a revitaliza.

Diferente de todos que buscaram escrever ao estilo de Lovecraft, Borges reconfigura a escritura do estadunidense, não tentando imita-lo, mas deixando que sua memória seja

\footnotetext{
${ }^{11}$ Em contos como: "O Sul” e "O Fim".
} 
responsável pela obra. É a essa memória que Borges dedica seu conto, como também aos resquícios deixados por Lovecraft e ao diálogo que ele realizou com outros escritores. Diálogo que Borges pontua, retoma e amplia com a sua leitura-escritura. E é neste jogo entre memória e esquecimento que ele realiza o conto póstumo. No fluir da memória, que carrega em si traços marcantes de Poe aos quais Borges adiciona a sua memória literária, que se aproxima e se afasta da de Lovecraft. Neste constante aproximar e afastar configura-se o espaço intervalar no qual se realiza a escritura do conto. Borges resgata a obra de Lovecraft, revitalizando a tradição de sua escritura. Ao invés de uma simples recuperação de elementos e temas recorrentes na obra do escritor, ele consegue articulá-los sem medo de infiltrar sua própria presença na tessitura do conto. Sendo Lovecraft, sem deixar de ser Borges, e, o mais incrível, sendo presença estranha em seu próprio conto, ou melhor, no conto póstumo do Outro.

\section{Referências}

BALDERSTON, Daniel. El percursor velado: R. L. Stevenson en la obra de Borges . Borges studies on line. On Line. J. L. Borges Center for Studies \& Documentation. Disponível em: http://borges.uiowa.edu/bsol/bsbl.php. Acessado em 13 de jan 2002.

BORGES, Jorge Luis. Historia Universal da Infâmia \& Outras Histórias. São Paulo: Círculo do Livro.

. Discussão. Rio de Janeiro: Bertrand Brasil, 1994.

. História universal da infâmia \& outras histórias. São Paulo: Círculo do livro, s.d..

. O Aleph. Porto Alegre: Globo, 1972.

. Introducción a la literatura norteamericana. Madrid: Alianza Editorial, 2000.

. Ficções. $5^{\circ}$ ed. São Paulo: Globo, 1989.

. Otras inquisiciones. $2^{\mathrm{a}}$ ed. Buenos Aires, 1952.

El cuento policial. In: Obras completas, IV. Barcelona: Emec é, 1996.

Prólogo. In: . Obras completas, IV. Barcelona: Emec é, 1996.

. Edgar Allan Poe de Edward Shanks. In: . Obras completas, IV. Barcelona: Emec é, 1996.

; CASARES, Adolfo Bioy. Crônicas para Bustos Domecq. Biblioteca Alfa-Omega de Literatura Latino-Americana. Editora Alfa-Omega. 

1981.

; GUERRRERO, Margarita. O Livro dos Seres Imaginários. Porto Alegre: Globo,

BLOCH, Robert. Heritage of Horror. In: The best of H. P. Lovecraft: Bloodcurdling tales of horror and the macabre. USA: Del Rey Book, 1982.

Poe \& Lovecraft . In: Ambrosia. № 2, agosto de 1973.

GUERRERO-STRACHAN. Santiago Rodríguez. Idea de Edgar A. Poe en la obra crítica de Jorge Luis Borges. Borges studies on line. On Line. J. L. Borges Center for Studies \& Disponível em: http://borges.uiowa.edu/bsol/bsbl.php. Acessado em 13 de jan 2002

Disponível em: http://www.hum.au.dk/romansk/borges/bsol/srg.htm

HAWTHORNE, Nathaniel. A Casa das Sete Torres. São Paulo: Círculo do Livro. s.d..

LLOPIS, Rafael (seleção e tradução). Antología de cuentos de terror III. De Arthur Machen a H. P. Lovecraft. Madri: Alianza Editorial, 1982.

LOVECRAFT, H. P. O Horror Sobrenatural na Literatura. Rio de Janeiro: Livraria Francisco Alves, 1987.

The best of H. P. Lovecraft: Horror Sobrenatural na Literatura: Bloodcurdling tales of horror and the macabre. USA: Del Rey Book, 1982.

. Um Sussurro nas Trevas. Rio de Janeiro: Livraria Francisco Alves, 1982.

. À Procura de Kadath. São Paulo: Editora Iluminuras, 1998.

. A cor que caiu do céu. São Paulo: Editora Iluminuras, 1998.

O Caso de Charles Dexter Ward. Porto Alegre, L\&PM, 1988.

MONEGAL, Emir Rodrígues. Borges por Borges. Porto Alegre: L\&PM, 1987.

NITRINI, Sandra. Literatura Comparada. São Paulo: EDUSP, 1997.

PERRONE-MOISÉS, Leyla. A Fantástica Verdade de Clarice. In: Flores na escrivaninha. São Paulo: Companhia das Letras, 1990.

PASTORMERLO, Sergio. Borges y la traducción. Borges studies on line. On Line. J. L. Borges Center for Studies \& Documentation. Disponível em: http://borges.uiowa.edu/bsol/bsbl.php. Acessado em 13 de jan 2002

POE, Edgar Allan. Contos Escolhidos. MENDES, Oscar; AMADO, Milton (Trad.). Rio de Janeiro: Globo, 1985.

RODRIGUES, Selma Calasans. O fantástico. São Paulo: Ática. Série Princípios, 1988. 
SANTIS, Pablo de: Un secreto amante de la ciencia ficcion: Crónicas borgeanas. Clarin, Buenos Aires, 22 de Agosto de 1999.

SARLO, Beatriz. Borges, un escritor en las orillas. Borges studies on line. On Line. J. L. Borges Center for Studies \& Documentation. Disponível em: http://borges.uiowa.edu/bsol/bsbl.php. Acessado em 13 de jan 2002.

Borges en su laberinto. Borges studies on line. On Line. J. L. Borges Center for Studies \& Documentation. Disponível em: http://borges.uiowa.edu/bsol/bsbl.php. Acessado em 13 de jan 2002.

Cómo Borges fue Borges?. Borges studies on line. On Line. J. L. Borges Center for Studies \& Documentation. Disponível em: http://borges.uiowa.edu/bsol/bsbl.php. Acessado em 13 de jan 2002.

SHAKESPEARE, William. Hamlet. Porto Alegre: L\&PM, 1999.

TODOROV, Tzvetan. Introducción a la literatura fantástica. Buenos Aires: Editorial Tiempo Contemporâneo, 1972.

VEGA, José Fernández. Una campaña estética. Borges y la narrativa policial. Borges studies on line. On Line. J. L. Borges Center for Studies \& Documentation. Disponível em: http://borges.uiowa.edu/bsol/bsbl.php. Acessado em 13 de jan 2002. 